\title{
HUBUNGAN ANTARA KADAR LACTATE DEHYDROGENASE (LDH) DENGAN LUARAN KLINIS PASIEN SEPSIS DI RSUD Dr. SAIFUL ANWAR
}

\author{
Muhammad Anshory ${ }^{\star \star}$, Gusti Rajendra Yoga Pratama**, Agustin Iskandar ${ }^{* * *}$
}

\begin{abstract}
Abstrak
Di seluruh dunia, sepsis adalah penyebab utama kematian. Insiden sepsis telah berlipat ganda selama beberapa tahun terakhir. Terdapat peradangan sistemik pada sepsis yang menyebabkan disfungsi organ. Dengan demikian, kita membutuhkan biomarker untuk menentukan diagnosis dan prognosis sepsis. Lactate dehydrogenase (LDH) adalah biomarker kerusakan organ terkait sepsis. Tujuan penelitian ini adalah untuk mengevaluasi hubungan antara LDH dan luaran klinis pasien dengan sepsis di RSUD Dr. Saiful Anwar Malang. Studi ini dilakukan menggunakan pendekatan kohort prospektif, sementara desainnya adalah analitik observasional. Pengambilan sampel dilakukan dengan metode konsekutif. Pemeriksaan kadar LDH dilakukan menggunakan Roche Cobas 8000, kemudian mortalitas dan lama perawatan dikumpulkan dari catatan medis. Temuan menunjukkan bahwa tidak ada variasi kadar LDH dalam hubungannya dengan kematian pada pasien sepsis $(p=0,414)$ dan ada hubungan negatif antara kadar LDH dengan lama perawatan pasien sepsis $(r=-0,576, p=0,031)$, tidak ada hubungan antara kadar LDH dan kematian pasien sepsis $(r=0,14, p=0,414)$. Didapatkan nilai cut-off LDH untuk memprediksi kematian adalah $728 \mathrm{U} /$, dengan nilai risiko relatif 1,28 . Pengukuran $\mathrm{LDH}$ yang hanya satu kali dianggap berdampak pada temuan laporan ini. Studi ini menyimpulkan bahwa pada pasien sepsis, kadar LDH memiliki hubungan yang moderat dengan lama perawatan, tetapi tidak memiliki hubungan pada kematian pasien sepsis.
\end{abstract}

Kata kunci: laktat dehidrogenase, lama perawatan, mortalitas, sepsis.

\section{RELATIONSHIP BETWEEN LACTATE DEHYDROGENASE (LDH) LEVEL AND THE CLINICAL OUTCOME OF SEPSIS PATIENT ADMITTED TO Dr. SAIFUL ANWAR PUBLIC HOSPITAL}

\begin{abstract}
Worldwide, sepsis is the major cause of death. The number of new cases of sepsis has multiplied during these recent years. Inflammation in sepsis occurs in the whole body, causing dysfunction of many organs. Thus, we need a biomarker to define the diagnosis and outcome of sepsis, which is one of them is lactate dehydrogenase $(\mathrm{LDH})$. The goal of this study was to evaluate the relationship between the level of LDH and outcomes of patient with sepsis at Dr. Saiful Anwar public hospital Malang. The study was done using prospective cohort approach, while the design was observational analytics. Consecutive sampling was the sampling process used. LDH was assessed using Roche Cobas 8000 , then mortality and duration of stay collected from medical records. The findings showed that there were no variations in LDH levels dependent on mortality in sepsis patients $(p=0.414)$ and that there was a negative association between the level of LDH and length of stay in patient with sepsis $(r=-0.576, p=0.031)$, there was no association among the level of LDH, and the mortality of patients with sepsis $(r=0.14, p=0.414)$. The mortality prediction cut-off for $\mathrm{LDH}$ was $728 \mathrm{U} / \mathrm{l}$, with a relative risk value of 1.28 . Only one period was conducted for LDH testing and sepsis control. This was thought to impact the findings of this report. The study concluded that LDH levels had a moderate correlation with the hospital stay duration, but no relationship with mortality rate in sepsis patients.
\end{abstract}

Keywords: lactate dehydrogenase, length of stay, mortality, sepsis.

*Departemen Ilmu Penyakit Dalam, Fakultas Kedokteran, Universitas Brawijaya

${ }^{* *}$ Program Studi Kedokteran, Fakultas Kedokteran Universitas Brawijaya

${ }^{* * *}$ Departemen Patologi Klinik, Fakultas Kedokteran, Universitas Brawijaya

E-mail: muhammadanshory@ub.ac.id 


\section{Pendahuluan}

Insiden sepsis di seluruh dunia semakin meningkat dari tahun ke tahun. Berdasarkan penelitian Fleischmann et al. (2016) di Jerman, pada tahun 2007 kasus sepsis berjumlah 200.535 dan pada tahun 2013 jumlah meningkat menjadi 279.530. Pada tahun 2013 juga didapatkan data pasien meninggal karena sepsis berjumlah 67.849 orang. ${ }^{1}$ Di Indonesia pada tahun 2009 , kasus kematian akibat syok sepsis adalah $49 \%$ dan naik menjadi $55 \%$ pada tahun $2011 .{ }^{2}$ Lebih lanjut, penelusuran data rekam medis di RSUD Dr. Saiful Anwar Malang pada tahun 2012 sampai 2013 ditemukan 1.026 pasien terdiagnosa sepsis dan 788 di antaranya meninggal dunia $(76,8 \%)$. Khusus di ruang Intensive Care Unit (ICU), terdapat 168 pasien sepsis dan 78 di antaranya meninggal dunia $(46,4 \%){ }^{3}$

Biomarker sangat diperlukan untuk menentukan diagnosa dan prognosa sepsis. Salah satunya adalah laktat dehidrogenase yang merupakan enzim metabolik yang dapat dideteksi dalam serum. Enzim ini berfungsi sebagai katalisator pembentukan laktat melalui proses glikolisis dan glukoneogenesis. ${ }^{4}$ LDH meningkat pada kondisi sepsis di mana terjadi kerusakan atau kematian sel pada organ sehingga terjadi peningkatan kadar LDH di ekstraselular. ${ }^{5}$

Penelitian ini menggunakan LDH sebagai biomarker karena dapat menentukan hubungan antara metabolisme glukosa dan mortalitas pada pasien sepsis. ${ }^{6}$ Adanya peningkatan kadar LDH yang signifikan akan berkorelasi dengan peningkatan mortalitas, serta tidak terjadinya penurunan kadar $\mathrm{LDH}$ dalam waktu 48 jam menandakan perburukan keadaan pada pasien sepsis, sehingga diperlukan deteksi dini untuk mengurangi mortalitas pasien sepsis. ${ }^{7}$

Sampai saat ini, belum ada penelitian terkait hubungan LDH dengan mortalitas dan lama rawat pasien sepsis di di RSUD Dr.
Saiful Anwar Malang, sehingga perlu dilakukan penelitian untuk mengetahui hubungan antara kadar LDH dengan outcome pasien sepsis, yaitu mortalitas dan lama rawat. Tujuan penelitian ini adalah mengetahui hubungan antara LDH dengan luaran klinis pasien sepsis di RSUD Dr. Saiful Anwar Malang.

\section{Bahan dan Metode}

Penelitian ini menggunakan metode analitik observasional dengan pendekatan kohort prospektif. Populasi penelitian ini adalah seluruh pasien sepsis yang dirawat di RSUD Dr. Saiful Anwar Malang periode November 2018-April 2019. Metode pemilihan subjek adalah consecutive sampling. Jumlah subjek adalah 36 pasien berdasarkan kriteria sepsis-3 tahun 2016 dengan skor SOFA $\geq 2$ yang memenuhi kriteria inklusi antara lain berusia lebih dari 18 tahun, ada fokus infeksi, serta data rekam medis yang lengkap, sedangkan eksklusinya antara lain adalah pasien sepsis dengan penyakit lain seperti ginjal, hepar, kardiovaskular dan hematologi. LDH subjek diukur dengan Roche COBAS 8000. Pasien diikuti dan diamati apakah terjadi kematian atau tidak selama 28 hari, serta ditentukan lama perawatan. Subjek penelitian variabel lama rawat adalah 13 pasien yang survive. Penelitian ini telah dinyatakan laik etik oleh Komisi Etik Penelitian Kesehatan RSUD Dr. Saiful Anwar dengan nomor: 400/105/ K.3/302/2018.

Data dianalisis menggunakan SPSS versi 25. Untuk mengetahui distribusi data dilakukan uji normalitas menggunakan uji Kolmogorov Smirnov. Uji beda dilakukan menggunakan uji $T$ tidak berpasangan. Untuk menentukan hubungan dilakukan uji korelasi menggunakan uji korelasi Pearson. Penentuan cut-off kadar LDH dilakukan menggunakan kurva ROC. Untuk melakukan perhitungan Relative Risk digunakan tabel $2 \times 2$. 
Hasil

Pada penelitian didapatkan jumlah subjek penelitian adalah 36 pasien dengan pasien laki-laki sebanyak 20 orang dan pasien perempuan sebanyak 6 orang. Karakteristik subjek pada penelitian ini dapat dilihat pada Tabel 1. Pada uji normalitas kadar LDH dengan mortalitas dan lama rawat didapatkan distribusi data normal $p=0,2(p>$ $0,05)$. Berdasarkan uji $T$ tidak berpasangan diperoleh $p=0,414(a<0,05)$, sehingga disimpulkan bahwa tidak ada perbedaan kadar LDH antara pasien survive dan nonsurvive. Pada uji korelasi didapatkan korelasi positif sangat lemah yang tidak bermakna antara kadar LDH dengan mortalitas $(r=0,14$; $p=0,414 ; a<0,05)$. Namun pada uji korelasi kadar LDH dengan lama rawat didapatkan $r=$ $-0,576(p=0,031 ; a<0,05)$, yang berarti terdapat korelasi negatif yang bermakna antara kadar LDH dengan lama rawat.

Berdasarkan hasil pengukuran kurva ROC pada Gambar 1, didapatkan area under the curve adalah sebesar 0,562. Cut-off kadar
LDH adalah $728 \mathrm{U} / \mathrm{l}$ yang didasarkan pada nilai sensitivitas dan spesifisitas kadar LDH yang paling baik, yaitu $43 \%$ sensitivitas dan $70 \%$ spesifisitas. Berdasarkan hasil analisis Relative Risk didapatkan bahwa pasien sepsis dengan kadar LDH $728 \mathrm{U} / \mathrm{l}$ atau lebih memiliki kemungkinan 1,28 kali lebih besar (IK 95\%, Cl 0,794 - 2,074; $p=0,319$ ) mengalami mortalitas.

\section{Pembahasan}

Hasil penelitian menunjukkan 23 pasien sepsis yang meninggal berusia di atas 55 tahun. Hal ini ditunjang penelitian sebelumnya yang mengatakan bahwa angka mortalitas sepsis akan meningkat pada usia di atas 40 tahun. ${ }^{1}$ Di Indonesia, tepatnya di Rumah Sakit Prof.Dr. R. D. Kandou Manado didapatkan pasien sepsis didominasi oleh pasien yang berusia lebih dari 45 tahun. ${ }^{8}$ Terjadinya peningkatan insiden sepsis pada usia tua dikarenakan adanya disfungsi sistem imun atau disebut sebagai immunosenescene.

Tabel 1. Karakteristik subjek penelitian

\begin{tabular}{lccc}
\hline \multirow{2}{*}{ Variabel } & \multicolumn{2}{c}{ Luaran $(\mathrm{n}=36)$} & $\mathrm{p}$ - value \\
\cline { 2 - 4 } & Survive $(\mathrm{n}=13)$ & Non-survive $(\mathrm{n}=23)$ & \\
\hline Jenis Kelamin $(\mathrm{n}(\%))$ & $7(19,4)$ & $13(36,1)$ & 0,877 \\
$\quad$ Laki-laki & $6(16,7)$ & $10(27,8)$ & \\
$\quad$ Perempuan & $53,31( \pm 17,65)$ & $58,04( \pm 9,26)$ & 0,295 \\
Usia (tahun) (mean, $\pm \mathrm{SD})$ & $596,61( \pm 298,58)$ & $680,60( \pm 289,69)$ & 0,872 \\
Kadar LDH (U/I) (mean, $\pm \mathrm{SD})$ & $15,71( \pm 13,64)$ & $13,42( \pm 11,37)$ & 0,739 \\
Lama Rawat (hari) (mean, $\pm \mathrm{SD})$ & & & \\
Fokus Infeksi (n (\%)) & $6(46,2)$ & $9(39,1)$ & 0,681 \\
Respirasi & $2(15,4)$ & $2(8,7)$ & 0,540 \\
Urogenital & $2(84,6)$ & $6(73,9)$ & 0,458 \\
Saraf & $1(7,7)$ & 0 & 0,177 \\
Integumentary & $1(7,7)$ & $5(21,7)$ & 0,277 \\
Digestif & $1(7,7)$ & $1(4,3)$ & 0,674 \\
Musculosekeletal & &
\end{tabular}






Gambar 1. Kurva ROC LDH dan lama rawat.

Keterangan: Area under curve pada kurva ROC ini adalah sebesar 0,562.

Hal ini menjadi penyebab meningkatnya insiden infeksi pada usia tua. Peningkatan produksi sitokin proinflamasi juga berpengaruh pada mortalitas sepsis usia tua. ${ }^{9}$

Berdasarkan kriteria jenis kelamin, penelitian ini menunjukkan hasil bahwa lakilaki lebih banyak menderita sepsis dibandingkan perempuan serta mortalitas pada laki-laki juga lebih tinggi. Hal ini sejalan dengan penelitian Nasir et al. (2015) yang menjelaskan bahwa angka mortalitas pada laki-laki lebih besar daripada perempuan. ${ }^{10}$ Hal tersebut disebabkan oleh adanya hormon estrogen pada perempuan yang dapat menjaga fungsi kardiovaskular, termasuk fungsi endotel sehingga komorbiditas pada laki-laki meningkat. ${ }^{11}$

Berdasarkan hasil uji beda tidak didapatkan perbedaan yang bermakna antara kadar LDH pasien survive dengan pasien yang non-survive $(p=0,414 ; a<0,05)$. Hasil penelitian ini tidak sesuai dengan hasil penelitian lain yang menyimpulkan bahwa terdapat perbedaan kadar LDH yang signifikan pada pasien sepsis yang hidup dan meninggal $(p=0,001) .12$ Kemungkinan tidak adanya perbedaan pada penelitian ini dikaitkan dengan pengambilan sampel LDH. Pada penelitian ini pengambilan sampel LDH dilakukan ketika hari pertama pasien didiagnosa sebagai sepsis. Hal ini berbeda dengan penelitian yang dilakukan Miglietta et al. (2015) yang mengatakan bahwa kadar LDH diperiksa 2 kali yaitu pada hari ke-1 sepsis dan hari ke-2 sepsis. ${ }^{13}$ Pada penelitian lain juga disebutkan bahwa pemeriksaan LDH dilakukan minimal $>1$ kali untuk melihat perkembangan pasien. ${ }^{14}$

Berdasarkan uji korelasi kadar LDH dengan mortalitas didapatkan hasil yang tidak signifikan ( $r=0,14 ; p=0,414 ; a<0,05)$. Hasil ini bertolak belakang dengan penelitian yang dilakukan oleh Lu et al. (2018) yang menyimpulkan bahwa terdapat korelasi positif antara kadar LDH dengan mortalitas pasien sepsis selama 28 hari $(\mathrm{HR} 1,004$; IK $95 \%, \mathrm{Cl}$ $1,001-1,007 ; p=0,009) .6$ 
Tidak adanya korelasi antara kadar LDH dengan mortalitas pada pasien sepsis mungkin dikarenakan banyak komorbid yang mempengaruhi mortalitas pada sepsis. Menurut penelitian yang dilakukan oleh McPherson D et al. pada tahun 2001-2010 terdapat beberapa komorbid yang mempengaruhi mortalitas pada sepsis, antara lain adalah kanker $(16,8 \%)$, diabetes $(9,4 \%)$, gagal ginjal kronis $(5,6 \%)$, penyakit saluran nafas bawah kronis $(6,1 \%)$, dan penyakit liver kronis $(2,7 \%))^{15}$

Berdasarkan hasil uji korelasi kadar $\mathrm{LDH}$ dengan lama rawat inap didapatkan nilai $r=-0,576(p=0,031 ; a<0,05)$. Hal tersebut menunjukkan bahwa terdapat korelasi negatif yang bermakna antara kadar LDH dengan lama rawat pasien sepsis. Penelitian oleh Zein et al. (2004) mengatakan bahwa tidak terjadinya penurunan kadar LDH dalam waktu 48 jam akan memperburuk keadaan pasien sepsis. ${ }^{7}$ Terdapat korelasi negatif antara kadar LDH dengan lama rawat pasien sepsis kemungkinan dikarenakan pasien dengan kadar LDH yang tinggi mendapatkan penanganan segera karena terdapat kerusakan organ yang masif. Asumsi ini sesuai dengan penelitian oleh Seymour et al. (2017) yang mengatakan bahwa pasien sepsis yang mendapatkan penanganan 3 bundle (kultur darah, pemberian antibiotik, dan pengukuran kadar laktat) dalam 3 jam akan menurunkan risiko kematian (OR 1,04; IK 95\%, Cl 1,02-1,05; p<0,001).8, 16

Berdasarkan hasil analisis Relative Risk didapatkan pasien sepsis dengan kadar LDH $\geq 728 \mathrm{U} / \mathrm{l}$ mempunyai risiko mortalitas 1,28 kali, namun hasil tersebut tidak bermakna (95\% Cl: $0,794-2,074 ; p=0,319)$. Tidak bermaknanya RR kadar LDH terhadap mortalitas pada pasien sepsis kemungkinan dikarenakan banyak faktor yang mempengaruhi peningkatan kadar LDH. Asumsi ini sesuai dengan penelitian yang dilakukan oleh Erez et al. (2014) yang mengatakan bahwa kadar LDH yang tinggi dapat dipengaruhi oleh komorbid, yaitu metastasis liver dan kanker $(p<0,0001) \cdot{ }^{14}$ Penelitian lain menunjukkan adanya 5 isoenzim pada LDH yang bermakna untuk mempengaruhi kadar LDH total. Isoenzim LDH tersebar pada seluruh sel, namun terkonsentrasi di jantung, otot, dan ginjal. Peningkatan dari salah satu isoenzim LDH dapat mempengaruhi kadar total LDH, seperti peningkatan LDH-1 dan LDH-2 yang menandakan kerusakan pada jantung dan otot. ${ }^{17}$

\section{Kesimpulan}

Kesimpulan dari penelitian ini adalah bahwa didapatkan korelasi negatif moderat yang bermakna antara kadar LDH dan lama perawatan, namun tidak didapatkan korelasi yang bermakna antara kadar LDH dengan mortalitas pasien sepsis pada penelitian ini. Terdapat peningkatan risiko mortalitas pada pasien dengan kadar LDH lebih tinggi namun tidak bermakna secara statistik.

\section{Saran}

Perlu dilakukan pemeriksaan kadar LDH sebagai prediktor mortalitas pada secara serial agar memperoleh hasil yang lebih akurat. Pemeriksaan kadar LDH pada masing -masing isoenzim dilakukan untuk menentukan kerusakan organ secara spesifik.

\section{Daftar Pustaka}

1. Fleischmann C, Thomas-Rueddel DO, Hartmann $M$, Hartog CS, Welte $T$, Heublein S, Dennler U, Reinhart K. Hospital Incidence and Mortality Rates of Sepsis: An Analysis of Hospital Episode (DRG) Statistics in Germany from 2007 to 2013. Deutsches Ärzteblatt International. 2016;113(10):159. 
2. Kemenkes RI. Profil Kesehatan Republik Indonesia Tahun 2017. Kementerian Kesehatan RI. Jakarta. 2017.

3. Andyk A. Problematika Penanganan Sepsis, Ketamin Awal Sebuah Pemikiran. Malang: Universitas Brawijaya Press. 2017.

4. Liu R, Cao J, Gao X, Zhang J, Wang L, Wang B, Guo L, Hu X, Wang Z. Overall Survival of Cancer Patients with Serum Lactate Dehydrogenase Greater than 1000 IU/L. Tumor Biology. 2016; 37 (10):14083-8.

5. Vania, E., Kusmiati, T. Hubungan Pneumocystis jirovecii Pneumonia dan Peningkatan Kadar Laktat Dehidrogenase Serum pada Pasien HIV. Karya Akhir. Surabaya: FK Universitas Airlangga-RSUD dr. Soetomo. 2017; 96101.

6. Lu J, Wei Z, Jiang $H$, Cheng $L$, Chen $Q$, Chen $M$, Yan J, Sun $Z$. Lactate Dehydrogenase is Associated with 28Day Mortality in Patients with Sepsis: a Retrospective Observational Study. Journal of Surgical Research. 2018; 228:314- 21.

7. Zein JG, Lee GL, Tawk M, Dabaja M, Kinasewitz GT. Prognostic Significance of Elevated Serum Lactate Dehydrogenase (LDH) in Patients with Severe Sepsis. Chest. 2004; 126(4):873S.

8. Tambajong RN, Lalenoh DC, Kumaat L. Profil Penderita Sepsis di ICU RSUP Prof. Dr. RD Kandou Manado Periode Desember 2014-November 2015. eCliniC. 2016; 4(1).

9. Starr ME, Saito H. Sepsis in Old Age: Review of Human and Animal Studies. Aging and Disease. 2014; 5(2):126.

10. Nasir N, Jamil B, Siddiqui S, Talat N, Khan FA, Hussain R. Mortality in Sepsis and Its Relationship with Gender. Pakistan Journal of Medical Sciences. 2015; 31(5):1201.
11. Angele MK, Pratschke S, Hubbard WJ, Chaudry IH. Gender Differences in Sepsis: Cardiovascular and Immunological Aspects. Virulence. 2014; 5(1):12-9.

12. Arvind MN, Nayana HK. Prediction of Outcome in Patients with Sepsis using CRP, LDH and Apache-II Scoring System. Journal of Evolution of Medical and Dental Sciences. 2018; 7(3):273-9.

13. Miglietta $F$, Faneschi ML, Lobreglio $G$, Palumbo C, Rizzo A, Cucurachi $M$, Portaccio G, Guerra F, Pizzolante M. Procalcitonin, C-Reactive Protein and Serum Lactate Dehydrogenase in the Diagnosis of Bacterial Sepsis, SIRS and Systemic Candidiasis.Infez Med. 2015; 23(3):230-7.

14. Erez A, Shental O, Tchebiner JZ, LauferPerl M, Wasserman A, Sella T, GuznerGur H. Diagnostic and Prognostic Value of Very High Serum Lactate Dehydrogenase in Admitted Medical Patients. Isr Med Assoc J. 2014; 16 (7):439.

15. McPherson D, Griffiths $C$, Williams $M$, Baker A, Klodawski E, Jacobson B, Donaldson L. Sepsis-Associated Mortality in England: an Analysis of Multiple Cause of Death Data from 2001 to 2010. BMJ Open. 2013; 3(8):e002586.

16. Seymour CW, Gesten F, Prescott HC, Friedrich ME, Iwashyna TJ, Phillips GS, Lemeshow S, Osborn T, Terry KM, Levy MM. Time to Treatment and Mortality during Mandated Emergency Care for Sepsis. New England Journal of Medicine. 2017; 376(23):2235-44.

17. Tietze KJ. Clinical Skills for Pharmacist. 3rd Edition. Philadelphia: Elsevier. 2012. P. 29-42. 